\title{
Sudden Death Caused by Fulminant Bacterial Infection: Background and Pathogenesis of Japanese Adult Cases
}

\author{
Takuma Tajiri ${ }^{1}$, Genshu Tate ${ }^{1}$, Katsutoshi Miura ${ }^{2}$, Shinji Masuda ${ }^{3}$, Nobuyuki Ohike ${ }^{4}$, \\ Toshiaki Kunimura ${ }^{4}$, Toshiyuki Mitsuya ${ }^{1}$ and Toshio Morohoshi ${ }^{4}$
}

\begin{abstract}
Objective To analyze a risk factor for the onset of fulminant bacterial infection.

Patients and Methods Nine unexpected acute death cases were clinicopathologically analysed. All cases represented the sudden onset of shock symptom, led to acute death within a few days, and later bacteremia was identified. Pathogens were Streptococcus pneumoniae (S. pneumoniae) (5 cases), group A beta Hemolytic Streptococcus pyogenes (S. pyogenes) (3 cases), and Vibrio vulnificus (V. vulnificus) (1 case).

Results Seven of the nine patients had underlying chronic illness. S. pneumoniae infection was associated with splenic dysfunction, and group A beta Hemolytic S. pyogenes and V. vulnificus infections were associated with alcoholic liver injury. Group A beta hemolytic S. pyogenes and V. vulnificus infections involved necrotizing fasciitis, and alcoholic liver cirrhosis was confirmed in two of the four patients.

Conclusion Despite the different type of bacteria, the onset of fulminant bacterial infection depended upon depressed bacterial phagocytosis in the liver or spleen. Underlying chronic illnesses should be identified as a predisposing common risk factor. It is important to understand the relations between underlying chronic illness and the onset of fulminant infection.
\end{abstract}

Key words: autopsy, fulminant bacterial infection, alcoholic liver injury, necrotizing fasciitis, splenectomy

(Inter Med 47: 1499-1504, 2008)

(DOI: 10.2169/internalmedicine.47.1160)

\section{Introduction}

Fulminant bacterial infection can cause sudden onset of sepsis and multiple organ failure, leading to death within a few days (1-3). Since the identification of group A beta hemolytic Streptococcus pyogenes ( $S$. pyogenes) in the 1980s, cases of flesh-eating bacteria have been reported (17). Fulminant infections by Vibrio vulnificus (V. vulnificus) (8-10) and Streptococcus pneumoniae (S. pneumoniae) (1116) have been also introduced. Once infected, the patient's condition deteriorates within hours, and emergent therapy is necessary. Mortality rates for flesh-eating bacterial infections are as follows: $15 \%-34 \%$ for group A beta hemolytic S. pyogenes $(1,2,4,5,7), 50 \%-75 \%$ for $V$. vulnificus (by primary septicemia) $(8,9)$, and $40 \%-60 \%$ for $S$. pneumoniae $(11-13$,
16).

A suspicion of malpractice can arise in cases of unexpected death. Recently, developed streptococcus grouping latex kits may be useful for early diagnosis $(17,18)$. However, the false negative results as well as the possibility of another bacteria such as $S$. pneumoniae are possible. There have been numerous reports on the molecular mechanisms of fulminant bacterial infection $(1,5,6,8,11-16)$. However, there are few reports on the general pathologic features of fulminant bacterial infection in Japan $(10,19)$. Here, the findings from nine cases of fulminant bacterial infection were examined.

\section{Patients and Methods}

Nine patients had visited Showa University Fujigaoka

\footnotetext{
${ }^{1}$ Department of Pathology, Showa University Fujigaoka Hospital, Yokohama, ${ }^{2}$ Department of Nursing Biohealthscience, Hamamatsu Medical University, Shizuoka, ${ }^{3}$ Department of Pathology, Koseiren Takaoka Hospital, Toyama and ${ }^{4}$ The First Department of Pathology, Showa University School of Medicine, Tokyo

Received for publication March 26, 2008; Accepted for publication May 26, 2008

Correspondence to Dr. Takuma Tajiri, takumatajiri1003@yahoo.co.jp
} 
Table 1. Clinical Information for Cases of Fulminant Infection

\begin{tabular}{|c|c|c|c|c|c|c|c|}
\hline No & $\begin{array}{l}\text { Age, } \\
\text { sex }\end{array}$ & $\begin{array}{l}\text { Chief } \\
\text { complaint }\end{array}$ & History & $\begin{array}{l}\text { Septic } \\
\text { shock }\end{array}$ & Bacteria & Culture & $\begin{array}{l}\text { Onset } \\
\text { to death }\end{array}$ \\
\hline 1 & $74, \mathrm{M}$ & $\begin{array}{l}\text { shock } \\
\text { syndrome }\end{array}$ & unknown & $(+)$ & $\begin{array}{l}\text { S.pneumoniae } \\
(23 \mathrm{~F})\end{array}$ & blood & 1 day \\
\hline 2 & $43, M$ & $\begin{array}{l}\text { dyspnea, } \\
\text { vomiting }\end{array}$ & $\begin{array}{l}\text { splenectomy } \\
\text { due to HSC }\end{array}$ & $(+)$ & S.pneumoniae & blood & 3 days \\
\hline 3 & $32, F$ & $\begin{array}{l}\text { throat } \\
\text { pain }\end{array}$ & $\begin{array}{l}\text { splenectomy } \\
\text { due to ITP }\end{array}$ & $(+)$ & $\begin{array}{l}\text { S.pneumoniae } \\
(12 \mathrm{~F})\end{array}$ & $\begin{array}{l}\text { blood, tonsil } \\
\text { cerebrospinal }\end{array}$ & 2 days \\
\hline 4 & $43, M$ & dyspnea & unknown & $(+)$ & S.pneumoniae & $\begin{array}{l}\text { blood, } \\
\text { sputum }\end{array}$ & 3 days \\
\hline 5 & $57, \mathrm{~F}$ & $\begin{array}{l}\text { vomiting, } \\
\text { diarrhea }\end{array}$ & $\begin{array}{l}\text { alcohol hepatic injury } \\
\text { appendicitis }\end{array}$ & $(+)$ & $\begin{array}{l}\text { group } A \text { beta } \\
\text { HSP }\end{array}$ & $\begin{array}{l}\text { blood, } \\
\text { pharynx }\end{array}$ & 3 days \\
\hline 6 & $73, \mathrm{M}$ & $\begin{array}{l}\text { vertigo, } \\
\text { limb pain }\end{array}$ & $\begin{array}{l}\text { subtotal } \\
\text { (stomach) }\end{array}$ & $(+)$ & $\begin{array}{l}\text { group A beta } \\
\text { HSP }\end{array}$ & $\begin{array}{l}\text { blood, pleural } \\
\text { effusion }\end{array}$ & 1 day \\
\hline 7 & $57, \mathrm{M}$ & $\begin{array}{l}\text { limb pain, } \\
\text { diarrhea }\end{array}$ & $\begin{array}{l}\text { alcohol hepatic injury } \\
\text { gallstone }\end{array}$ & $(+)$ & Vibrio vulnificus & blood, stool, & 3 days \\
\hline 8 & $61, M$ & dyspnea & $\begin{array}{l}\text { alcohol hepatic injury } \\
\text { emphysema }\end{array}$ & $(+)$ & S.pneumoniae & blood, sputum & 5 days \\
\hline 9 & $84, F$ & limb pain & $\begin{array}{l}\text { mamma ca } \\
\text { colon ca }\end{array}$ & $(+)$ & $\begin{array}{l}\text { group } A \text { beta } \\
(\mathrm{T} 11, \mathrm{speB}+\mathrm{C})\end{array}$ & blood & 4 days \\
\hline & $\begin{array}{l}\text { ITP, idi } \\
\text { HSC, h } \\
\text { HSP, h } \\
\text { M, male } \\
\text { F, fema }\end{array}$ & $\begin{array}{l}\text { opathic thro } \\
\text { ereditary sp } \\
\text { emolytic } S t \\
\text { le }\end{array}$ & $\begin{array}{l}\text { bocytopenic purpura } \\
\text { erocytosis } \\
\text { ptococcus pyogenes }\end{array}$ & & $\begin{array}{l}\text { No, case number } \\
\text { ca, carcinoma } \\
\text { S. Streptococcus }\end{array}$ & & \\
\hline
\end{tabular}

Hospital and other hospitals during the period 1999 through 2008 and had unfortunately died; - seven of these nine cases were subjected to autopsy. Autopsy was performed because of sudden unknown death, and infectious bacterial pathogens were later identified in blood cultures. Criteria for the diagnosis of fulminant infection include bacteremia and unexpected death within a few days after the acute onset of shock symptoms. Five patients had S. pneumoniae infection, three had group A beta hemolytic $S$. pyogenes infection, and one had V. vulnificus infection. Cases 5, 6 and 9 were diagnosed according to the criteria established by the working group on severe S. pyogenes infections (3), Also, Case 7 was of $V$. vulnificus induced septicemia (sudden onset of systemic symptoms) within 24 hours of eating seafood (shellfish) in the summer (9). Thoracotomy and ventrotomy were performed in five cases, and thoracotomy, ventrotomy, and craniotomy were performed in two cases. Informed consent was obtained from the families of all patients, and the study was performed in accordance with the Declaration of Helsinki (1975).

\section{Histologic examinations}

Resected tissue specimens were fixed at autopsy in $10 \%$ neutral-buffered formalin and embedded in paraffin. Threemicron-thick sections were generated and stained with Hematoxylin and Eosin and examined microscopically. Each tissue sample was analyzed histopathologically. When the existence of bacteria was suspected histologically, the tissue was subjected to Gram and Giemsa staining.

\section{Detection of bacteria}

Microbiologic blood cultures were performed in SN and
SA bottles (Japan, bioMerieux, Tokyo) and analyzed with BacT/ALERTt (bioMerieux). When a positive signal was obtained, the sample was incubated on sheep blood agar (M 58), chocolate agar, and subjected Brucella HK agar and subjected to Gram staining to isolate and identify the organism. S. pneumoniae was identified as an $\alpha$-hemolytic, Grampositive coccus sensitive to des deoxycholic acid (10\%) and optochin (ethylhydrocupreine- $\mathrm{HCl}$ ). S. pyogenes was identified as a $\beta$-hemolytic, Gram-positive coccus sensitive to bacitracin and negative to catalase. V. vulnificus was identified as a glucose-fermentable Gram-negative bacillus sensitive to oxidase and tolerant to $3 \%$ sodium chloride (peptone water) (ID test; EB20 kit; Nissui Pharmacentical, Tokyo, Japan).

\section{Results}

\section{Clinical findings}

Nine patients were analyzed in the study. The mean age was 57.8 years (range, 32-84 years) (Table 1). Six were males, and three were females. The patients experienced rapidly progressive bacterial infection characterized by septic shock, leading to multiple organ involvement. The capsular type of $S$. pneumoniae was $23 \mathrm{~F}$ in Case 1 and $12 \mathrm{~F}$ in Case 3. Group A beta hemolytic $S$. pyogenes in case 9 was identified in the strain of T-agglutination (serotype 11), and possessed S. pyogenes exotoxin B and C genes. Five patients with $S$. pneumoniae infection experienced sudden onset of shock symptoms, and two of the four patients with group A beta $S$. pyogenes or $V$. vulnificus infection experienced gastrointestinal involvement and melalgia with shock 
Table 2. Autopsy Findings in Cases of Fulminant Vacterial Infection

\begin{tabular}{|c|c|c|c|c|c|c|c|}
\hline & $\begin{array}{l}\text { Necrotizing } \\
\text { fasciitis }\end{array}$ & Lung & $\begin{array}{l}\text { Spleen } \\
\text { weight }\end{array}$ & $\begin{array}{l}\text { Adrenal } \\
\text { bleeding }\end{array}$ & $\begin{array}{l}\text { Bacteria } \\
\text { location }\end{array}$ & $\begin{array}{l}\text { Cause } \\
\text { of death }\end{array}$ & Background \\
\hline 1 & $(-)$ & $\begin{array}{l}\text { congestion } \\
\text { and bleeding } \\
\text { pneumonia }(-)\end{array}$ & $120 \mathrm{~g}$ & $(-)$ & $\begin{array}{l}\text { Gram (+) } \\
\text { diplococci, } \\
\text { various organs }\end{array}$ & $\begin{array}{l}\text { circulatory } \\
\text { collapse }\end{array}$ & $\begin{array}{l}\text { Plasma cell } \\
\text { myeloma }\end{array}$ \\
\hline 2 & $(-)$ & $\begin{array}{l}\text { congestion } \\
\text { and bleeding } \\
\text { pnemumonia (-) }\end{array}$ & S & $(+)$ & $\begin{array}{l}\text { Gram (+) } \\
\text { diplococci, } \\
\text { heart, lung, } \\
\text { kidney }\end{array}$ & $\begin{array}{l}\text { circulatory } \\
\text { collapse, } \\
\text { subarachnoid } \\
\text { bleeding }\end{array}$ & not confirmed \\
\hline 3 & $(-)$ & $\begin{array}{l}\text { congestion } \\
\text { and bleeding } \\
\text { pneumonia (-) }\end{array}$ & $S$ & $(+)$ & $\begin{array}{l}\text { Gram (+) } \\
\text { diplococci, } \\
\text { tonsil, heart, } \\
\text { lung, kidney }\end{array}$ & $\begin{array}{l}\text { circulatory } \\
\text { collapse }\end{array}$ & not confirmed \\
\hline 4 & $(-)$ & $\begin{array}{l}\text { congestion } \\
\text { and bleeding } \\
\text { pneumonia (-) }\end{array}$ & $60 \mathrm{~g}$ & $(+)$ & not confirmed & $\begin{array}{l}\text { circulatory } \\
\text { collapse } \\
\text { subarachnoid } \\
\text { bleeding }\end{array}$ & not confirmed \\
\hline 5 & $\begin{array}{l}(+) \\
\text { left arm }\end{array}$ & $\begin{array}{l}\text { congestion } \\
\text { and bleeding } \\
\text { pneumonia }(-)\end{array}$ & $90 \mathrm{~g}$ & $(+)$ & $\begin{array}{l}\text { Gram (+) } \\
\text { coccus } \\
\text { left arm }\end{array}$ & $\begin{array}{l}\text { circulatory } \\
\text { collapse }\end{array}$ & $\begin{array}{l}\text { liver } \\
\text { cirrhosis }\end{array}$ \\
\hline 6 & $\begin{array}{l}(+) \\
\text { left limb }\end{array}$ & $\begin{array}{l}\text { congestion } \\
\text { pneumonia (-) }\end{array}$ & $75 \mathrm{~g}$ & $(-)$ & $\begin{array}{l}\text { Gram (+) } \\
\text { coccus } \\
\text { left limb, lung }\end{array}$ & $\begin{array}{l}\text { circulatory } \\
\text { collapse }\end{array}$ & not confirmed \\
\hline 7 & $\begin{array}{l}(+) \\
\text { shoulder, } \\
\text { legs }\end{array}$ & $\begin{array}{l}\text { congestion } \\
\text { and bleeding } \\
\text { pneumonia (-) }\end{array}$ & $190 \mathrm{~g}$ & $(-)$ & not confirmed & $\begin{array}{l}\text { circulatory } \\
\text { collapse }\end{array}$ & $\begin{array}{l}\text { liver } \\
\text { cirrhosis }\end{array}$ \\
\hline
\end{tabular}

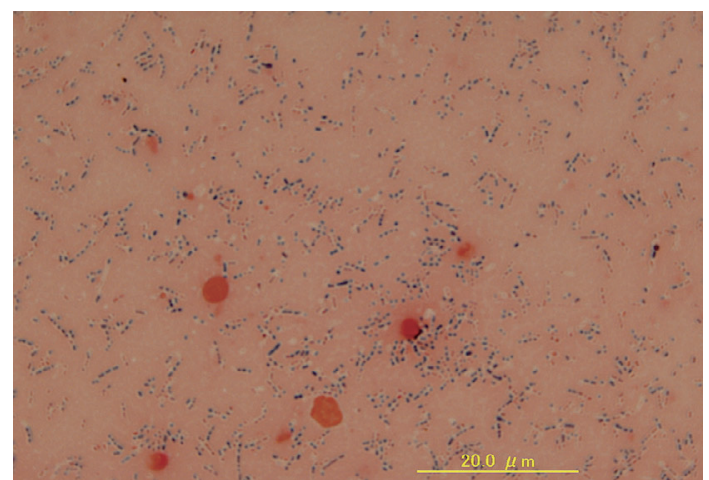

Figure 1. Gram staining of sputum in Patient 8. Numerous gram-positive cocci are linked side by side, with no observation of polymorphonuclear leukocytes.

symptoms. Seven of nine patients had an underlying chronic disease. In addition, two of the five patients with S. pneumoniae infection had a history of splenectomy for treatment of a hematologic disorder, and three patients were alcohol abusers, one of them also had $S$. pneumoniae infection. Three of the five patients with $S$. pneumoniae infection had a hematologic disorder (13), and three patients had alcoholic hepatic injury. No clinical information was available for two patients. An antibiotic therapy was not available in several cases because of acute death. Also, an emergent incision and debridement to treat necrotizing fasciitis could not be undertaken except for case 7 because general condition was deteriorated. No improvements were observed in any of the cases despite intensive care treatment. In Case 1, chemotherapy for treatment of hematologic malignancy was not per- formed. Also, emergent gram staining of sputum in case 8 showed numerous diplococci (Fig. 1A), and urinary antigen of $S$. pneumoniae was also confirmed. Also, V. vulnificus was also confirmed in the smear of an emergent archenteron of incision in the left shoulder.

\section{Autopsy findings}

On postmortem examinations performed seven of the nine dead cases (except cases 8, 9), showed petechiae on the body surface and subcutaneous hemorrhages, consistent with Disseminated intravascular coagulation (DIC) (Table 2). Group A beta $S$. pyogenes and $V$. vulnificus infections involved necrotizing fasciitis (Fig. 2) $(1,5,6)$. Some patients showed blisters from the epidermis to the dermis $(19,20)$. Pulmonary congestion complicated by bacterial colonization was observed (Fig. 3) (20-23). Four of the seven patients showed adrenocortical hemorrhage (24). Histopathologically, Gram-positive diplococci were confirmed in three of the four patients with $S$. pneumoniae infection. In Case 1, numerous bacteria in various organs were also observed (Fig. 4). Gram-positive cocci of group A beta S. pyogenes in two patients were present around the necrotizing fasciitis (Fig. 5); however, colonization by V. vulnificus was not identified. Death was attributed to rapid progressive sepsis due to bacteremia, leading to circulatory collapse. Subarachnoid bleeding caused by circulatory collapse was present in two cases. In the cases of pneumococcal infection, plasma cell myeloma was identified after death $(13,25,26)$. Two of the three patients with group A beta S. pyogenes and $V . v u l$ nificus infection showed alcoholic liver cirrhosis $(1,5,8$ 10). 


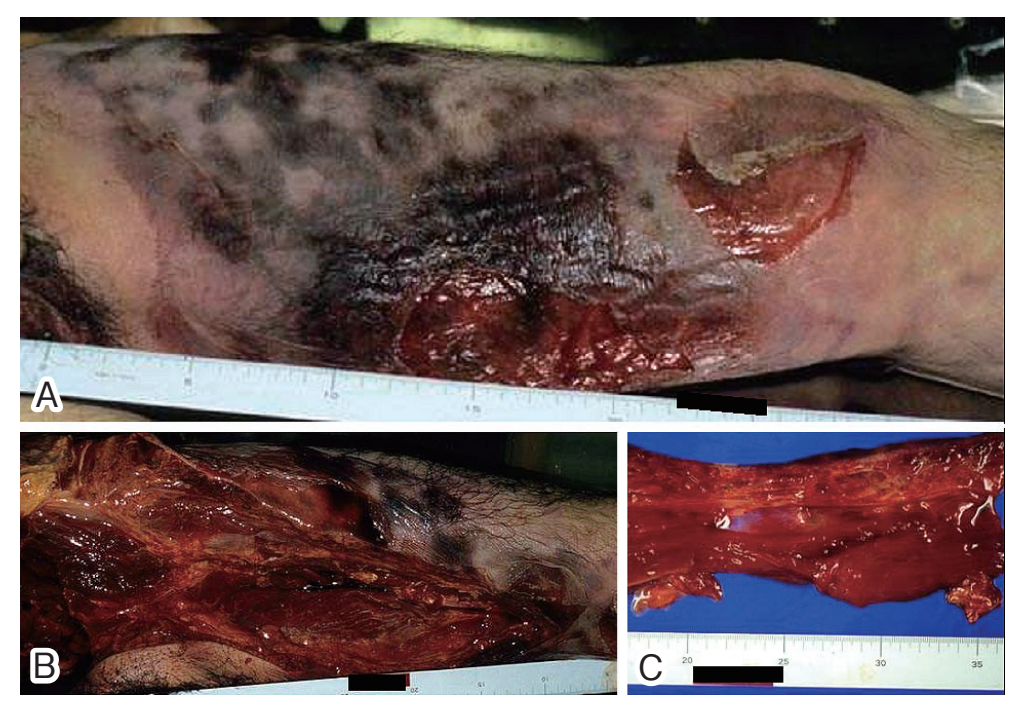

Figure 2. Gross findings of patient 6. (A) Desquamation and erosion with bluish-purple discoloration of the left inner femur. (B) Incision of the left inner femur shows subcutaneous hemorrhage and necrosis. (C) Hemorrhagic and necrotic muscle and fascia.
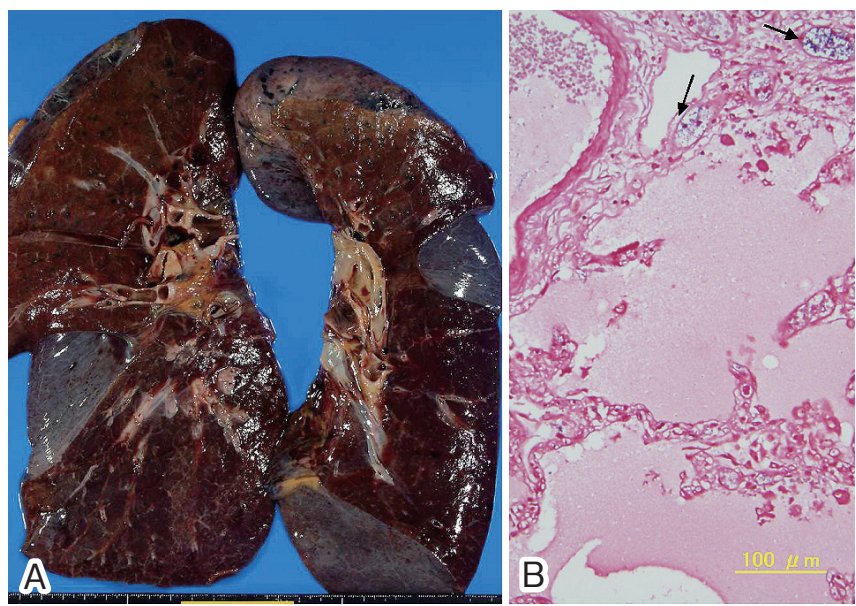

Figure 3. Gross and histologic findings of the lung in patient 1. (A) Severe right hemorrhagic pulmonary congestion (lung weight, 980 g). (B) Pulmonary congestion complicated by bacterial colonies (arrows) (Hematoxylin and Eosin staining).

\section{Discussion}

Fulminant bacterial infections are mainly categorized as $S$. pneumoniae or group A beta hemolytic $S$. pyogenes and $V$. vulnificus infections. The former is associated with splenectomy, whereas the latter are associated with liver dysfunction and necrotizing fasciitis. The spleen comprises $25 \%$ of the body's lymph tissue, and is involved in bacterial phagocytosis, antigen presentation, and opsonin production. Splenic macrophages are more efficient than neutrophils with respect to trapping in the blood, especially in bacterial phagocytosis $(11,12,14,16,27)$. Also, the polysaccharide capsule of $S$. pneumoniae makes it resistant to phagocytosis. Opsonin and specific antibodies to the polysaccharide capsule are significantly reduced with splenectomized patients;

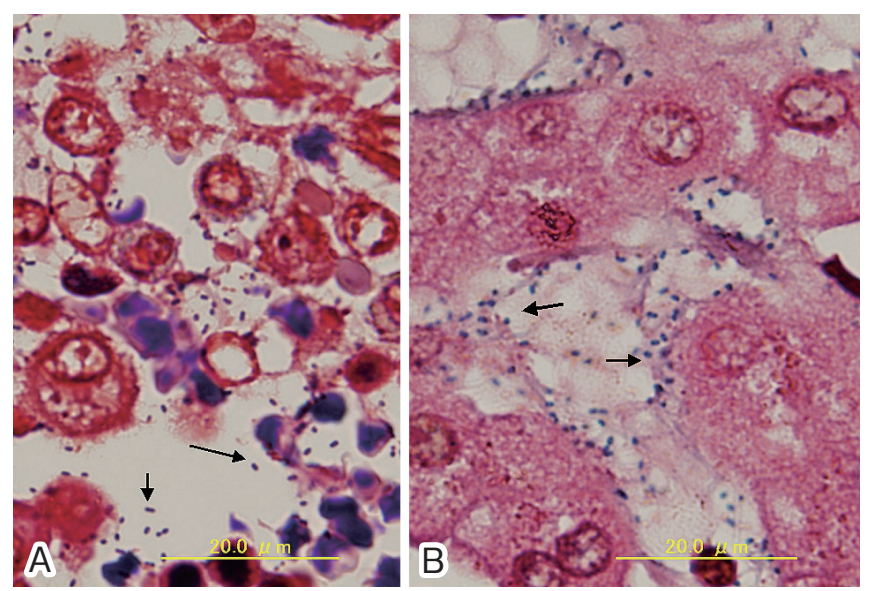

Figure 4. Histologic findings of patient 1. (A) Bone marrow shows numerous Gram-positive diplococci (arrows) (Gram stain). (B) Hepatic sinusoid shows numerous Gram-positive diplococci (arrows) (Gram stain).

once the patient is infected, can occur readily bacteremia. Patients who have undergone splenectomy as treatment for reticuloendothelial disorders such as hematologic disease are susceptible to $S$. pneumoniae infection $(11,13,14)$. No splenic dysfunction of three patients without histories of splenectomy was confirmed, however, it seems that immunocompromised state based on the depressed phagocytosis such as plasma cell myeloma (case 1) and an alcoholic liver injury (case 8) may have played a role in the onset of $S$. pneumoniae infection. Therefore, the possibility of $S$. pneumoniae infection is not always denied despite the lack of history of splenectomy. The Waterhouse-Friderichsen (WF) syndrome is a clinicopathological entity consisting of sudden onset of a rapidly progressive illness, shock, cyanosis, a petechial rash, haemorrhages in both adrenal glands, and death usually within 24 hours. In the present study, it seems that the collapse of adrenocortical sinusoids caused 


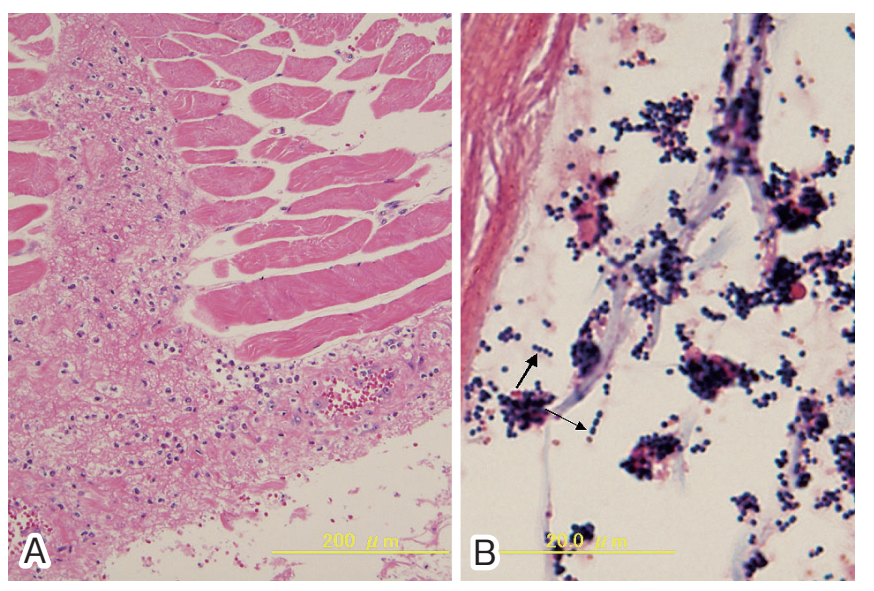

Figure 5. Histologic and bacterial findings of patient 6. (A) Subcutis shows inflammation surrounded by fibrin adjacent to torn muscle fibers (Hematoxylin and Eosin staining). (B) Numerous Gram-positive cocci are linked side by side (arrows) (Gram stain).

by the sepsis played a role in the development of adrenal hemorrhages $(19,24)$.

Alcoholic liver cirrhosis was confirmed at autopsy in two patients with group A beta $S$. pyogenes or $V$. vulnificus. The presence of alcoholic liver cirrhosis makes regulation of the host immune response difficult. Kupper cell depletion is associated with decreased activity of the reticuloendothelial system, and the presence of sinusoidal compression due to pericellular fibrosis facilitates the formation of arteriovenous shunts. Impairment of the host defense system can lead to bacteremia $(28,29)$. It appears that bacteria resistant to phagocytosis invade the blood from the intestinal tract and migrate to the liver via the portal vein, at which point marked bacterial proliferation and bacteremia occur (29). The pathogenesis of alcoholic liver injury caused by depressed bacterial phagocytosis depends on the onset of fulminant infection (29). V. vulnificus infection associated with eating seafood such as raw oyster and shellfish in the summer must be distinguished from group A beta hemolytic $S$. pyogenes $(10,30)$.

The cause of death in each case is circulatory collapse caused by fulminant infection $(10,19)$. Bacterial infection may not be identified at first histologic assessment. Also, the initial focus of bacteria except for case 3 was unknown probably due to the very early entry of bacteria into circulation. Once infection occurs, it produces endotoxin derived from lipopolysaccharide caused by $S$. pneumoniae and $V$. vulnificus, or produces large amounts of cytokines caused by the host-immune response to the toxic superantigen by group A beta hemolytic $S$. pyogenes, leading to acute volume loss $(3,4,20-23,31-37)$. The onset of fulminant infection depends on the bacteria and the sensitivity of the host (38). In the present study, depressed bacterial phagocytosis such as splenic dysfunction or liver dysfunction was a predisposing common risk factor for the onset of fulminant bacterial infection $(28,29,37)$.

A search of the literature found splenectomy in $91.9 \%$ of patients with fulminant $S$. pneumoniae infection (14), liver dysfunction in 10\%-20\% of patients with group A beta hemolytic $S$. pyogenes infection $(1,5,7,21,39)$, and liver dysfunction in $66 \%-90.3 \%$ of patients with $V$. vulnificus infection $(8,36,40)$, which supports our data. Clinically, empiric antibiotic therapy should be performed at first after examining cultures $(21,27)$, and underlying chronic illnesses should be identified. There are no published data comparing fulminant infection classified according to the type of bacteria, and each patient with depressed phagocytosis in liver or splenic dysfunction is a common risk factor. Analysis of additional cases of fulminant infection is needed to elucidate the pathogenic mechanisms involved. A general physician should always keep the possibility of fulminant bacterial infection in mind when examining patients with shock symptoms because the mortality rate of the disease depends on the first primary intensive care.

\section{References}

1. Stevens DL, Tanner MH, Winship J, et al. Severe group A streptococcal infections associated with a toxic shock-like syndrome and scarlet fever toxin A. N Engl J Med 321: 1-7, 1989.

2. Hoge CW, Schwartz B, Talkington DF, Breiman RF, MacNeill EM, Englender SJ. The changing epidemiology of invasive group A streptococcal infections and the emergence of streptococcal toxic shock-like syndrome. A retrospective population-based study. JAMA 269: 384-389, 1993.

3. The Working Group on Severe Streptococcal Infections. Defining the group A streptococcal toxic shock syndrome. Rationale and consensus definition. JAMA 269: 390-391, 1993.

4. Barry W, Hudgins L, Donta ST, Pesanti EL. Intravenous immunoglobulin therapy for toxic shock syndrome. JAMA 267: 33153316, 1992.

5. Davies HD, McGeer A, Schwartz B, et al. Invasive group A streptococcal infections in Ontario, Canada. Ontario Group A Streptococcal Study Group. N Engl J Med 335: 547-554, 1996.

6. Chelsom J, Halstensen A, Haga T, Hoiby EA. Necrotising fasciitis due to group A streptococci in western Norway: incidence and clinical features. Lancet 344: 1111-1115, 1994.

7. Kaul R, McGeer A, Low DE, Green K, Schwartz B. Populationbased surveillance for group A streptococcal necrotizing fasciitis: clinical features, prognostic indicators, and microbiologic analysis of seventy-seven cases. Ontario Group A Streptococcal Study. Am J Med 103: 18-24, 1997.

8. Blake PA, Merson MH, Weaver RE, Hollis DG, Heublein PC. Disease caused by a marine Vibrio. Clinical characteristics and epidemiology. N Engl J Med 300: 1-5, 1979.

9. Hlady WG, Mullen RC, Hopkin RS. Vibrio vulnificus from raw oysters. Leading cause of reported deaths from foodborne illness in Florida. J Fla Med Assoc 80: 536-538, 1993.

10. Tajiri T, Tate G, Akita H, et al. Autopsy cases of fulminant-type bacterial infection with necrotizing fasciitis: Group A (beta) hemolytic Streptococcus pyogenes versus Vibrio vulnificus infection. Pathol Int 57: 606-612, 2008.

11. Waghorn DJ. Overwhelming infection in asplenic patients: current best practice preventive measures are not being followed. J Clin Pathol 54: 214-218, 2001. 
12. Jugenburg M, Haddock G, Freedman MH, Ford-Jones L, Ein SH The morbidity and mortality of pediatric splenectomy: does prophylaxis make a difference? J Pediatr Surg 34: 1064-1067, 1999.

13. Bisharat N, Omari H, Lavi I, Raz R. Risk of infection and death among post-splenectomy patients. J Infect 43: 182-186, 2001.

14. Cullingford GL, Watkins DN, Watts AD, Mallon DF. Severe late postsplenectomy infection. Br J Surg 78: 716-721, 1991.

15. Landgren O, Bjorkholm M, Konradsen HB, et al. A prospective study on antibody response to repeated vaccinations with pneumococcal capsular polysaccharide in splenectomized individuals with special reference to Hodgkin's lymphoma. J Intern Med 255: 664673, 2004.

16. Working Party of the British Committee for Standards in Haematology Clinical Haematology Task Force. Guidelines for the prevention and treatment of infection in patients with an absent or dysfunctional spleen. BMJ 312: 430-434, 1996.

17. Vicca AF, Stansfield RE, Masterton RG. Evaluation of new streptococcal latex grouping kit. J Clin Pathol 46: 79-80, 1993.

18. Davies S, Gear JE, Mason CM, McIntyre SM, Hall L. Streptococcus grouping latex kits: evaluation of five commertially available examples. Br J Biomed Sci 60: 136-140, 2003.

19. Tajiri T, Tate G, Enosawa $T$, et al. Clinicopathological findings in fulminant-type pneumococcal infection: report of three autopsy cases. Pathol Int 57: 606-612, 2007.

20. Bryant AE, Kehoe MA, Stevens DL. Streptococcal pyrogenic exotoxin $\mathrm{A}$ and streptolysin $\mathrm{O}$ enhance polymorphonuclear leukocyte binding to gelatin matrixes. J Infect Dis 166: 165-169, 1992.

21. Ekelund K, Skinhoj P, Madsen J, Konradsen HB. Reemergence of emml and a changed superantigen profile for group A streptococci causing invasive infections: results from a nationwide study. J Clin Microbiol 43: 1789-1796, 2005.

22. Jevon GP, Dunne WMJr, Hawkins HK, Armstrong DL, Musser JM. Fatal group A streptococcal meningitis and toxic shock-like syndrome: case report. Clin Infect Dis 18: 91-93, 1994.

23. Hor LI, Chang YK, Chang CC, Lei HY, Ou JT. Mechanism of high susceptibility of iron-overloaded mouse to Vibrio vulnificus infection. Microbiol Immunol 44: 871-878, 2000.

24. Fox B. Disseminated intravascular coagulation and the Waterhouse-Friderichsen syndrome. Arch Dis Child 46: 680-685, 1971.

25. Gowda R, Razvi FM, Summerfield GP. Risk of pneumococcal septicaemia in patients with chronic lymphoproliferative malignancies. BMJ 311: 26-27, 1995.

26. Grogan TM, Van Camp B, Kyle RA, Muller-Hermelink HK, Harris NL. Plasma cell neoplasms. In: Pathology and Genetics of Tumours of Haematopoietic and Lymphoid Tissues. IARC Press, Lyon, 2001: 142-148.
27. Goodman J, Newman MI, Chapman WC. Disorders of the spleen. In: Wintrobe's Clinical Hematology, Greer JP, Foerster J, Lukens JN, et al, Eds. 11th edn. Lippincott, Williams \& Wilkins, Philadelphia, PA, 2003: 1893-1909.

28. Lahnborg G, Friman L, Berghem L. Reticuloendothelial function in patients with alcoholic liver cirrhosis. Scand J Gastroenterol 16: 481-489, 1981.

29. Rimola A, Soto R, Bory F, Arroyo V, Piera C, Rodes J. Reticuloendothelial system phagocytic activity in cirrhosis and its relation to bacterial infections and prognosis. Hepatology 4: 53-58, 1984.

30. Osaka K, Komatsuzaki M, Takahashi H, Sakano S, Okabe N. Vibrio vulnificus septicaemia in Japan: an estimated number of infections and physicians' knowledge of the syndrome. Epidemiol Infect 132: 993-996, 2004.

31. Torres J, Bisno AL. Hyposplenism and pneumococcemia: Visualization of Diplococcus pneumoniae in the peripheral blood smear. Am J Med 55: 851-855, 1973.

32. Coonrod JD, Leach RP. Antigenemia in fulminant pneumococcemia. Ann Intern Med 84: 561-563, 1976.

33. Rytel MW, Dee TH, Ferstenfeld JE, Hensley GT. Possible pathogenetic role of capsular antigens in fulminant pneumococcal disease with disseminated intravascular coagulation (DIC). Am J Med 57: 889-896, 1974.

34. Espat NJ, Auffenberg T, Abouhamze A, Baumhofer J, Moldawer LL, Howard RJ. A role for tumor necrosis factor-alpha in the increased mortality associated with Vibrio vulnificus infection in the presence of hepatic dysfunction. Ann Surg 223: 428-433, 1996.

35. Shin SH, Shin DH, Ryu PY, Chung SS, Rhee JH. Proinflammatory cytokine profile in Vibrio vulnificus septicemic patients' sera. FEMS Immunol Med Microbiol 33: 133-138, 2002.

36. Sie MY, Ip-yam PC, Oon LL. Vibrio vulnificus septicaemia. Anaesth Intensive Care 30: 77-81, 2002.

37. Norrby-Teglund A, Thulin P, Gan BS, et al. Evidence for superantigen involvement in severe group A streptococcal tissue infections. J Infect Dis 184: 853-860, 2001.

38. Norrby-Teglund A, Muller MP, Mceer A, et al. Successful management of severe group A streptococcal soft tissue infections using an aggressive medical regimen including intravenous polyspecific immunoglobulin together with a conservative surgical approach. Scand J Infect Dis 37: 166-172, 2005.

39. Mehta S, McGeer A, Low DE, et al. Morbidity and mortality of patients with invasive group A streptococcal infections admitted to the ICU. Chest 130: 1679-1686, 2006.

40. Oishi H, Ura Y, Mitsumizo S, Nakashima M. A collective review of Vibrio vulnificus infection in Japan. Kansenshogaku Zasshi 80: 680-689, 2006 (in Japanese with English abstract).

(C) 2008 The Japanese Society of Internal Medicine http://www.naika.or.jp/imindex.html 